\title{
NOTES
}

\section{THE ILLUSTRATION AND TYPOGRAPHY OF SPECIMEN $D A Y S$, AND A LOST WHITMAN PORTRAIT FOUND}

The first illustrated edition of Specimen Days by Walt Whitman appeared in 1971, displaying the imprint of David R. Godine, Publisher, Boston. The book, which contained a new introduction by Alfred Kazin, received a positive review from Leo Marx in The New York Times Sunday Book Review. My name appears in the credit on the copyright page: "The book was designed, researched and edited by Lance Hidy."
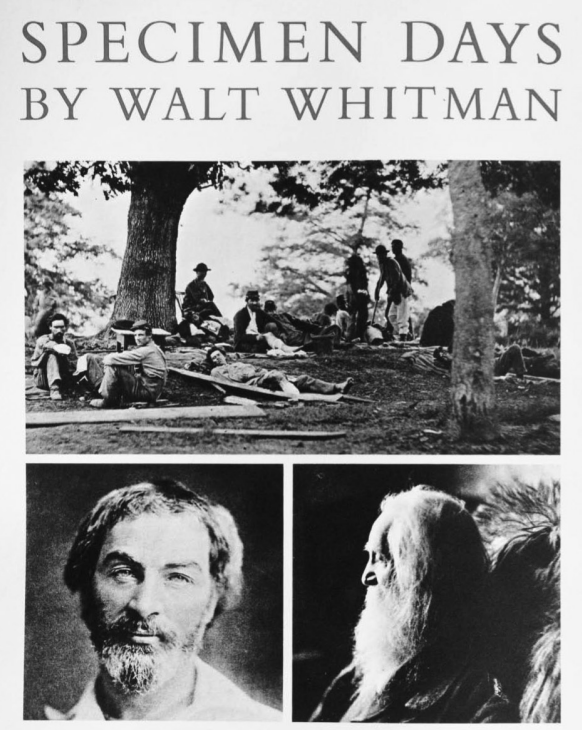

2* INTRODUCTION BY ALFRED KAZIN 2 ILLUSTRATED WITH 133 CIVIL WAR PHOTOGRAPHS \& SELECTED PORTRAITS

FROM THE LIFE OF WALT WHITMAN 2

As a visual learner who earned poor to mediocre grades in English at Yale, I would probably have been voted the least likely person in my class (1968) to be editor for such a book-especially at the age of 24 . The following story explains how this improbable event transpired. In addition, the editor of this journal, Ed Folsom, has asked me to tell how I became the owner of a lost photograph of Whitman made in 1889 by Frederick Gutekunst.

Much of the credit for this remarkable edition of Specimen Days goes to David Godine-who first had the idea, and then paid for it. It was also David who invited Alfred Kazin to write his essay. Just as I was the product of the undergraduate presses at Yale, David had his start in Ray Nash's Graphic Arts Workshop at Dartmouth. After being introduced to each other by our mentor Leonard Baskin, David invited me to help him start a private press. The plan was to issue fine, illustrated letterpress books that we would print ourselves, inspired by Baskin's Gehenna Press.

While I was making wood engravings, arranging typography, and running presses, David was hunting for neglected gems of American literature. Specimen Days was new to me, since, like most students, I had only heard of Leaves of Grass. When, at David's suggestion, I read it, I was stunned. I returned im- 
mediately to Leaves of Grass, which I then understood in a new way. For me, it was Specimen Days, rather than the poetry, that opened my understanding of the man.

Having agreed that we would publish Specimen Days, we then wanted to figure out how to illustrate it. For Whitman's description of the Civil War, David thought of using photographs by Matthew Brady. I had an idea that we could find several portrait photographs of Whitman too. With that, in 1970, I departed from Boston, alone in my Volkswagen bus. My first stop would be the Brady collection in the Library of Congress.

Meanwhile, my appetite for Whitman was growing. I read all of the prose works, along with several editions of Leaves. I tried to read everything written about Whitman by those who knew him. I even read Bucke's Cosmic Consciousness. By the time I checked into the YMCA in Washington, I was in a kind of Whitman reverie. This trance-like state of mind went deeper when I entered the Library of Congress. Unknown to me, the display cases in the huge exhibit hall were filled with Whitman memorabilia from the collection of Charles E. Feinberg: Walt's rucksack, tickets from his Lincoln lectures, books, pages of handwriting, and portraits.

Although I had spent many hours roaming the stacks at Yale's Sterling Memorial Library, searching for illustrated books, I had little experience in formal scholarly research. With the help of the LC staff, I was able to locate and order photographic copies of portraits of Whitman and other documents, as well as photographs selected from the file cabinets containing the Matthew Brady Civil War archive.

I made additional stops at the Duke University Library, the Walt Whitman House in Camden, the New York Public Library, and Yale's Beinecke Rare Book and Manuscript Library, where I still had friends among the library staff.

In New York, I had an appointment with Oliver Jensen, publisher of American Heritage magazine, to ask if he'd like to publish something connected to our illustrated edition of Specimen Days. Mr. Jensen was delightful, and although he declined to publish any of our material, he did offer me a job at the magazine-which I declined.

The staff at the Library of Congress told me how to contact Mr. Charles Feinberg. When I told Feinberg by telephone what I was doing, he insisted that I come to his home in Detroit as soon as possible so he could show me additional material from Whitman's Civil War period, and more portraits. He seemed as excited by our Specimen Days project as I was. While graciously acquiescing to every request to borrow photographs and documents, Feinberg, like Oliver Jensen, offered me a job on the spot. He suggested that I move to Detroit to help him organize his collections-but, once again, I declined.

The biggest surprise to come out of this research was the quantity of photographic portraits of Whitman. I finally had sixty-five of them, all of which would be beautifully reproduced in offset duotone, full page, by the Meriden Gravure Company. As large as that number seemed at the time, it was only half of the 128 portraits that are now published on the website of the Walt Whitman Archive. But in 1971, those sixty-five portraits seemed like a revelation, putting Whitman among the most-photographed people in the world during those early decades of photography. 
Evidently I was more interested in researching and editing the images than I was in textual matters. Regrettably, the copy that David and I sent to the Stinehour Press to be composed in Monotype Bembo was a poor choice, as we felt obliged to confess on the copyright page after it was too late to correct our error: "Spelling and punctuation have been changed to conform with modern usage." For the most part, this meant that contractions had been spelled out, and the apostrophes removed.

picking and a little farming. I was watching a group of young boatmen eating their early dinner-nothing but an immense loaf of bread, had apparently been the size of a bushel measure, from which they cut chunks with a jackknife. Must be a tremendous winter country this, when the solid frost and ice fully set in.

CEDAR-PLUMS LIKE - NAMES 20 BACK AGAIN IN CAMDEN AND DOWN IN JERSEY ONE time I thought of naming this collection "Cedar-Plums Like" (which I still fancy wouldn't have been a badname, nor inappropriate). A mélange of loafing, looking, hobbling, sitting, traveling - a little thinking thrown in for salt, but very little-not only summer but all seasonsnot only days but nights - some literary meditationsbooks, authors examined, Carlyle, Poe, Emerson tried (always under my cedar tree, in the open air, and never in the library)-mostly the scenes everybody sees, but some of my own caprices, meditations, egotism - truly an open-air and mainly summer formation-singly, or in clusters - wild and free and somewhat acrid-indeed more like cedar-plums than you might guess at first glance. $2 \vartheta$ But do you know what they are? (To city man, or some sweet parlor lady, I now talk.) As you go along roads, or barrens, or across country, anywhere through these states, middle, eastern, western, or southern, you will see, certain seasons of the year, the thick woolly tufts of the cedar mottled with bunches of chinablue berries, about as big as fox grapes. But first a special
Left: Sample of Monotype Bembo composed by The Stinehour Press, showing the use of leaf ornaments instead of line breaks within the mini-chapters of Specimen Days.

As proud as I was of the visual content, and of the design and printing of our volume, I was embarrassed by this flaw. I sent the finished book to Gay Wilson Allen, who never responded-a silence that I attributed, with a trace of paranoia, to our book's weakness, and to my being an impostor among the true Whitman scholars.

I have since recovered from my humiliation, recognizing that the book's visual content did make a significant contribution, bringing overdue recognition to a little-known masterpiece. Our Specimen Days was also a superb example of the fine bookmaking tradition that continues to keep me rooted in New England in 2009. Prior to this large project, I had only worked on small, limited editions, printed by myself, often illustrated with my etchings or wood engravings, and with type composed either by hand or by hot metal Monotype casters.

As much as I loved these hand-crafted, small-edition exercises, I quickly tired of their limited reach. I aspired to work in what seemed to me like the Major League of trade book publishing, epitomized for David and me by The Stinehour Press in Lunenburg, Vermont, and The Meriden Gravure Company in Meriden, Connecticut. These two organizations often collaborated, with Meriden printing the halftones, and Stinehour taking care of the typography.

At 224 pages, $83 / 8$ X 11 5/8 inches, Specimen Days was the first full-scale book design that I had undertaken. More importantly it gave me a chance to work with the skilled book arts people at Meriden and Stinehour. The 
lessons I learned there, especially regarding photographic reproduction and typographic planning for complex books, provided a foundation that I am still building upon today.

Now I'd like to mention the odd structure of the text of Specimen Days because it had a strong effect upon the book's unorthodox design. The text was characterized by the author in his first paragraph: “. . . untie the bundle, reel out diary scraps and memoranda, just as they are, large or small, one after another, into print pages, and let the mélange's lacking and wants of connection take care of themselves." Consequently, each page spread had four to six mini-chapters, each with its own title, and sometimes a date.

These ultra-short chapters often consisted of a single paragraph, or two or three. To the typographer, this brevity provided the luxury of separating paragraphs only by the insertion of a leaf ornament mid-line, rather than the usual practice of starting on a new, indented line. In normal metal composition, such linking of paragraphs was too risky. For example, if a word was repeated by mistake, not only would its paragraph need to be reset, but all the text that flowed after it would have to be reset too. In the economics of metal composition, one could not risk having to reset more than one paragraph at a time.

But for this edition of Specimen Days I did what I have never done since-I used the second duotone color for the leaf ornaments to indicate the start of a new paragraph. While many people may not be conscious of this treatment, it contributes to the integrity of the pages, where the only line spaces occur before the title of a new section.

One other unusual feature of the design is the table of contents. Each of the 215 sections has its own title. The list of titles reads like a poem. For example

\author{
THE WOMEN OF THE WEST \\ THE SILENT GENERAL \\ PRESIDENT HAYES'S SPEECHES \\ ST. LOUIS MEMORANDA \\ NIGHTS ON THE MISSISSIPPI \\ UPON OUR OWN LAND \\ EDGAR POE'S SIGNIFICANCE \\ BEETHOVEN'S SEPTET
}

A HINT OF WILD NATURE

LOAFING IN THE WOODS

A CONTRALTO VOICE

The surprising juxtapositions in this list were typical Whitman. This inspired me to use a grand and spacious typographic treatment, composing the table of contents in letter-spaced capitals, single column, on eight pagesthirty-six titles to a page. A wild extravagance. I wonder if anybody ever took the time to read the whole list.

During the years immediately following the publication of Specimen Days in 1971, I started collecting first editions of Whitman - at least the ones I could afford. One New York book dealer offered me a manila folder of miscellaneous Whitman items from the descendants of Thomas Harned, Whitman's friend 
and lawyer. The date was sometime between 1971 and 1974, and I remember paying $\$ 100$.

The prize of the batch was a beautiful Gutekunst portrait of Whitman which I had never seen - for if I had, it would have been included in the book. After enjoying the photograph for some 35 years, I decided to do a Google image search for Walt Whitman on a Sunday morning in April, 2009. I was surprised to find that this image was not included in the Walt Whitman Archive's collection of 128 portraits.
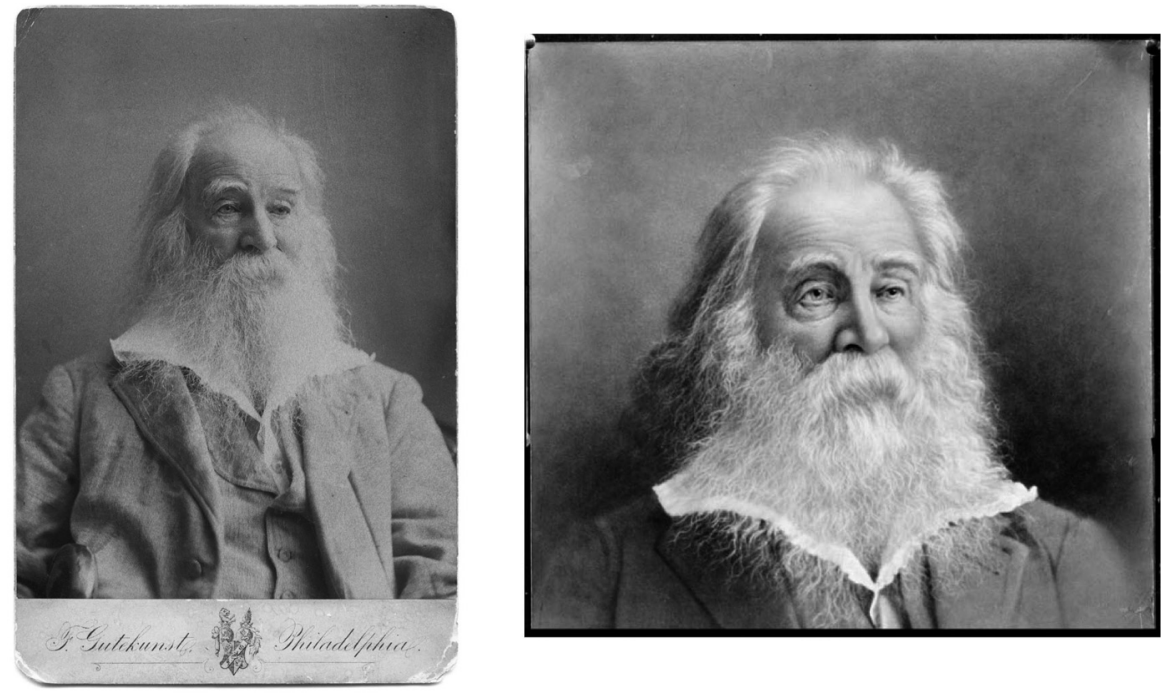

The 1889 Gutekunst photograph ( $4 \frac{3 / 4}{4} 61 \frac{1}{2}$," collection of Lance Hidy) is compared here with the painting reproduced on the back cover of the Spring 2008 issue of the Walt Whitman Quarterly Review. The reproduction of the photograph on the left has had scratches and the tone scale slightly adjusted in Photoshop by LH for greater clarity.
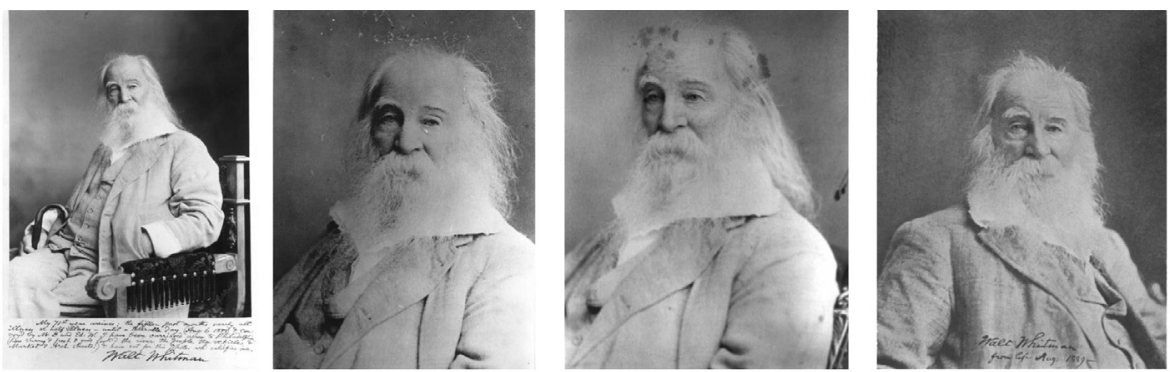

Above are the known photographs from the 1889 Gutekunst session. 
As it dawned on me that I might have a unique print, unknown to scholars, I sent a jpeg of my photograph to the first three staff names at the Whitman Archive. Two hours and forty-seven minutes later I received this e-mail from Ed Folsom:

I can't thank you enough for sending us that remarkable Gutekunst photograph of Whitman. This answers one mystery that has been haunting us for a couple of years. Many years ago, Geoffrey Sill, who teaches at Rutgers-Camden, was given an old damaged negative of an image of Whitman that had been handed down through generations of Camden, NJ, residents. Geoffrey shared the negative with us a few years ago, and we did the best we could to nudge the image out through Photoshop. Finally, Geoffrey had the negative restored, and when he made a print, he was astonished to find that what we had thought to be a photograph of Whitman actually emerged as a painting. It was clearly a painting based on a photograph (or, Geoffrey insisted, a heavily retouched photo), and clearly it derived from the Gutekunst sitting, but it was a photo none of us had seen. Now we have!

Also in the folder along with the photograph was a typewritten, unsigned copy of Whitman's will of May 15, 1873. A note is pencilled on the front:

\section{Supplement to \\ a will made in \\ 1872-Lost- \\ Original-Lost \\ The only known \\ Copy - to be \\ returned to \\ T. B. Harned}

As I learned from Ed Folsom, the manuscript version of this will is in the Barrett collection at the Alderman Library, University of Virginia. My copy is of typographic interest as an early example of typewriter type, which first appeared in 1873. Although the will is officially dated 1873 , it was probably copied by a typist sometime thereafter.

The manila folder also contained a letter from Evie Allison Allen, dated June 14, 1957, thanking Mrs. Harned for her hospitality when she and her husband Gay Wilson Allen visited. Thus the Harned family provenance of my Gutekunst photograph is established.

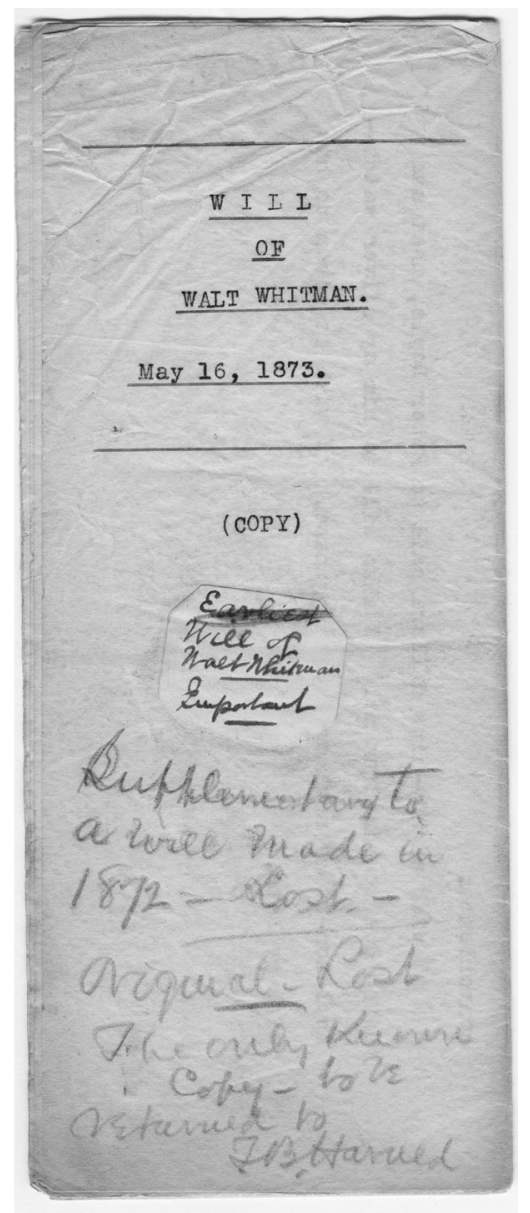


I long ago sold my Whitman editions, but I display the Gutekunst portrait where I can see it every day. I am grateful to Ed Folsom and the Walt Whitman Quarterly Review for allowing me to share it with you.

\section{AM I NOT A MAN AND A POET?: A RECENTLY RECOVERED WHITMAN CARICATURE}

The February 27, 1869, issue of Punch, Victorian England's premier satirical rag, features a previously undocumented article on Walt Whitman entitled "He is a Man." Punch, edited at the time by Mark Lemon (who co-founded the periodical along with Henry Mayhew), takes this opportunity to contradict painter and Atlantic Monthly art critic Eugene Benson, who claimed that, "[w] henever [Whitman] speaks, you hear the voice of a man in his agony, in his gladness, in his transports." Benson's rhapsodic praise of the American poet appears in his essay "Charles Baudelaire, Poet of the Malign" published in the same February 1869 issue of the Atlantic, where Whitman's "Proud Music of the Sea-Storm," ultimately titled "Proud Music of the Storm," was first printed. ${ }^{1}$ Punch's "He is a Man" reprints reactions to Benson's comments on Whitman from two other periodicals-Theodore Hagen's New York Weekly Review ${ }^{2}$ and Britain's preeminent music journal, Musical World, ${ }^{3}$ then edited by James William Davison. Accompanying the text of "He is a Man" is the racist caricature of a black male having his forehead shined and/or blackened while reclining on a sidewalk — an image entirely of Punch's own invention.

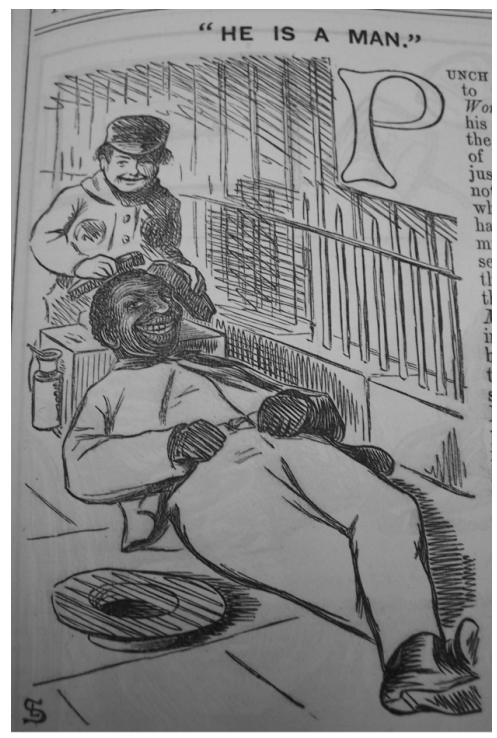

Punch-whose comedic affect Martha Banta describes as a merger of "cheeky, Cockney irreverence" and "sanctified British tradition" - had previously dismissed Leaves of Grass as proof that the "fields of American literature" needed "weeding dreadfully." Published thirteen years after this initial critique, "He is a Man" marks Punch's return to transatlantic Whitman-bashing. ${ }^{6}$ Punch begins its 1869 attack on Whitman by thanking Musical World for the opportunity to lampoon "such trash":

Punch is indebted to the Musical World for calling his attention to the following bit of keenness and justice. He did not see, at first, what the topic had to do with music; but, on second thoughts, the wisdom of the editor of the $M . W$. in extracting the passage became evident - those who praise such trash as Mr. Whitman's perform on the instrument called Fiddle-faddle, which the $M . W$. has of course a right to criticise:- 